\title{
Analgesic and Sedative-Hypnotic Potentiality of Crude Methanolic Extract of Gomphandra tetrandra (Wall.) Sleumer Leaves
}

\author{
(1) N. M. Mahmudul Alam BHUIYA1 (1) Md. Forman HOSSEN1, (1) Md. Monirul ISLAM², (1) Moynul HASAN* \\ 1 Jagannath University, Department of Pharmacy, Dhaka, Bangladesh \\ 2Northern University Bangladesh, Department of Pharmacy, Dhaka, Bangladesh
}

\begin{abstract}
Objectives: Gomphandra tetrandra (Wall.) Sleumer (leaves) belonging to the family Stemonuraceae was investigated for preliminary phytochemical screening and evaluating their pharmacological activities in various pharmacological models.

Materials and Methods: The crude methanolic extract was screened with different chemical reagents for the qualitative detection of different phytochemical groups. The peripheral analgesic function was determined using the acetic acid-induced writhing procedure and sedative-hypnotic behaviors were assessed using hole-board, open field, and hole-cross tests using different doses of the extract (200 mg/kg and $400 \mathrm{mg} / \mathrm{kg}$ body weight).

Results: Phytochemical screening revealed that methanolic extract of G. tetranda leaves contains steroids, gums, mucilages, phytosterols, carbohydrates, and flavonoids. The crude methanolic extract at $200 \mathrm{mg} / \mathrm{kg}$ and $400 \mathrm{mg} / \mathrm{kg}$ doses showed statistically significant activity in acetic acid-induced writhing inhibition test with 60\% ( $p<0.01)$ and $76.47 \%(p<0.01)$ inhibition, respectively, compared to control. The extract also had dosedependent substantial $(p<0.01)$ sedative-hypnotic activities compared with diazepam in the hole-board, open field, and hole-cross tests.

Conclusion: It may be assumed that the methanolic leaf extract of G. tetrandra possesses a strong possibility of having analgesic and sedativehypnotic activity due to the presence of bioactive compounds in its leaves. Moreover, observed results have opened a new era of in-depth research to discover the possible mechanism of analgesic and sedative-hypnotic activity.
\end{abstract}

Key words: Gomphandra tetrandra, methanolic extract, analgesics, sedative-hypnotic activity

\section{INTRODUCTION}

The use of plants in all major systems of medicine, regardless of the underlying philosophical premise, illustrates their universal function in treating diseases. 'Plant species are being depleted at a rapid rate; they cannot be botanically registered or chemically \& pharmacologically studied. Thus, it is essential to create an increased effort toward conserving gene pools. ${ }^{2}$

Natural sources are credited for the excellent revolution in modern medicine, and since the beginning, medicinal plants have played a crucial role in the field of drug discovery. Bangladesh is a well-known source of medicinal plants. ${ }^{3}$ Today, several medicines, such as morphine from Papaver somniferum L. and atropine from Atropa belladonna L., are extracted from medicinal plants. ${ }^{4,5}$ Secondary metabolites (potential drug sources) are present in significant amounts in medicinal plants. Medicinal plants are in high demand in both developing and developed countries because of these factors. ${ }^{6}$ In Bangladesh's rural and tribal communities, medicinal plants play a vital role in the socio-cultural, spiritual, and therapeutic spheres.

A survey conducted by the World Health Organization (WHO) in 1993 depicts that traditional practitioners treat about $80 \%$ of patients in India, $85 \%$ in Burma, and $90 \%$ in Bangladesh. The use of plants for medicinal purposes dates back to 40005000 B.C., and the Chinese were the first to use natural herbal preparations as medicines. Also, about $25 \%$ of all modern pharmacopeial drugs are plant-derived and many other 
synthetic analogs based on prototype compounds isolated from plants. $^{7}$

Gomphandra tetrandra (Wall.) Sleumer is a herbaceous plant species found in the forest, which belongs to the family Stemonuraceae (formerly Icacinaceae). This family has had a popular medicinal history for a long time in many countries globally, especially in the evergreen forest, tropical, and subtropical regions. 8,9 Various pharmacological investigations have already been conducted on different plants of this family. For example, Mappianthus iodoides Hand.-Mazz. is used to treat hepatitis, jaundice, rheumatalgia, and arthralgia..$^{10}$ Other studies revealed the hepatoprotective and hypoglycemic activity of Lasianthera africana P.Beauv. (Icacinacaeae/Stemonuraceae) in animal models.1112 L. africana leaves also showed potent in vitro antioxidant activity in DPPH free radical scavenging test. $^{13}$ In this study, we tried to explore the analgesic and neuropharmacological potential of the methanolic leaf extracts of $G$. tetrandra.

\section{MATERIALS AND METHODS}

\section{Collection of the plant}

G. tetrandra was collected from the Moulvibazar District, Bangladesh, for this study. One of the professional taxonomists at the Bangladesh National Herbarium, Mirpur, Dhaka, Bangladesh, identified the plant, and a voucher was deposited there for future reference with the plant identification number 51332. The desired plant parts (leaves) were separated from unwanted materials, plants or plant parts. Then, they were then allowed to dry for a week under light. Using a suitable grinder, the sun-dried leaves were converted into coarse powder. An airtight container was used to store the coarse powder. The container was kept in a cool, dark, and dry place till analysis was initiated.

\section{Preparation of $G$. tetrandra leaf extracts}

Approximately $400 \mathrm{~g}$ of powdered plant material was soaked in $2100 \mathrm{~mL}$ of $80 \%$ methanol in a clean, flat-bottomed glass vessel. The glass vessel was properly sealed and stored for seven days with periodic shaking and stirring. After that, the mixture was filtered twice, using a piece of clean cotton material and a cotton plug. The filtrate was evaporated until absolutely dry using a ceiling fan and a water bath. It produced a sticky material with a reddish-black color that was identified as crude methanol extract.

\section{Chemicals and solvents}

Different chemicals and solvents of analytical grade were used in this study, including methanol and acetic acid. They were purchased from a local supplier and were used directly. Eskayef Pharmaceuticals Ltd. (Bangladesh) and Orion Infusion Limited, Tejgaon (Dhaka, Bangladesh) supplied diclofenac sodium and $0.9 \% \mathrm{NaCl}$ solution, respectively. Incepta Pharmaceuticals Ltd. provided the diazepam, which was used as standard in neuropharmacological activity tests.
Phytochemical screening of methanol extracts of $G$. tetrandra leaf

The primary phytochemical studies include testing of various chemical groups present in the extract. Different chemical tests were accomplished to ensure the presence of carbohydrates (using Molisch reagent), tannins (using bromine water), alkaloids (using Wagner's reagent), saponins (foam formation by olive oil), flavonoids (using $\mathrm{NaOH}$ ), phenols (using $\mathrm{FeCl}_{3}$ solution), anthraquinone glycosides, cardiac glycosides, proteins, and gums \& mucilage (swelling properties). ${ }^{14}$

\section{Test animals}

Swiss-albino mice were obtained from the Jahangirnagar University's animal house, which were of both sexes, 4-5 weeks old and 20-30 g weight. They were held in a controlled environment and served ICDDR, B developed rodent food as well as water (ad libitum). During the experiments, the mice were chosen randomly and irrespective of sex and divided into different groups following the standard procedures. ${ }^{15}$ Since these mice are susceptible to habitat changes, they are held in the experimental condition for at least 3-4 days before the test. This study strictly adheres to globally recognized principles for standard use of experimental animal models developed by the International Council for Laboratory Animal Science and National Institutes of Health ${ }^{16,17}$ and finally approved by the Local Ethics Committee (ref. no: DoP/RC/EC/2020/06/02).

\section{Evaluation of analgesic activity by acetic acid-induced writhing test}

The writhing test is an experimental procedure for inducing peripheral pain in mice by administering irritants such as acetic acid. The test compound's analgesic efficacy is determined by a reduction in the number of writings. ${ }^{18}$ Twenty Swiss albino mice (weighing 20-30 g) were randomly taken and divided into four groups, each with five mice. Group I mice were given normal saline $(10 \mathrm{~mL} / \mathrm{kg}$ per body weight, orally), group II mice were given diclofenac sodium ( $50 \mathrm{mg} / \mathrm{kg}$ per body weight, orally) as a standard drug. In contrast, groups III and IV received methanolic extract (200 and $400 \mathrm{mg} / \mathrm{kg}$ per body weight, orally) as the sample. One hour after this treatment, $0.1 \mathrm{~mL}$ of $0.6 \%(\mathrm{v} / \mathrm{v})$ acetic acid was administered intraperitoneally. The animal's abdominal muscle writhing characterized by stretching with a twitch at the back limb was taken as writhing movement, which is an indicator of pain response. The number of writhing motions in individual mice was counted for 15 min after the acetic acid administration. The percentage inhibition of writhing was counted from the following equation:

Inhibition $(\%)=\frac{\text { Average writhing of control }- \text { Average writhing of sample }}{\text { Average writhing of control }} \times 100 \%$

Healthy Swiss albino mice of both sexes, 4-5 weeks old and 20-30 g weight, were used for the test. A positive control group was treated with diazepam (1 $\mathrm{mg} / \mathrm{kg}$ i.p.), and the negative control group was administered with vehicle $(10 \mathrm{~mL} / \mathrm{kg}$, normal saline orally). The test groups (groups II and III) received two different doses (200 and $400 \mathrm{mg} / \mathrm{kg}$, respectively) of $G$. 
tetrandra leaf extract by oral administration. The following three methods evaluated the sedative-hypnotic activity:

\section{i) Hole-board test}

Studying the exploratory activities of mice, this test is widely recognized as a way to assay potential sedative and anxiolytic effects of any compound. The equipment contained 16 equal size and evenly spaced holes. Normal saline $(0.1 \mathrm{~mL} / \mathrm{mice}$, p.o.) and diazepam (1 mg/kg, i.p.) were given to the control and standard groups, respectively. It was established that the animals' headdipping activity is directly relevant to their emotional situation. ${ }^{19}$ The mice were put on the perforated flat platform after a period of $30 \mathrm{~min}$ in the case of the control and crude extract, and 15 min in the case of the standard, and the head dips' number in a period of five minutes was registered.

\section{ii) Open field test}

It is performed to evaluate exploratory behavior and anxiety along with to evaluate anxiolytic, anxiogenic, and non-pharmacological treatment. The test was performed to assess the anxiolytic activity of the test compound in mice central nervous system (CNS) as described by Gupta et al. ${ }^{20}$ The open field apparatus consisted of a half-square-meter square wooden field with a series of squares painted in black and white alternately. The apparatus also contained a $30 \mathrm{~cm}$ high wall and was kept in a dimly lit place. The experimental animals were treated with vehicle, extract or diazepam and were held in the open field's center. After the treatment, the number of squares crossed by the animals was counted for $3 \mathrm{~min}$ at 30,60, 90, and $120 \mathrm{~min}$.

\section{iii) Hole cross test}

In this experiment, a cage with a dimension of $30 \times 20 \times 14 \mathrm{~cm}$ was used, with a fixed partition in the middle with a hole of $3 \mathrm{~cm}$ in diameter. ${ }^{21}$ Mice received either a negative control, standard or an extract before being allowed pass the hole from one chamber to the next. The animals were observed for $3 \mathrm{~min}$ and the number of passages was counted at $30,60,90$, and 120 min after the treatments.

In all three methods, the percent inhibition (\%) value was calculated as follows:

Inhibition $(\%)=\frac{\text { Reaction time }(\text { control })-\text { Reaction time }(\text { sample })}{\text { Reaction time }(\text { control })} \times 100 \%$

\section{Statistical analysis}

One-way ANOVA followed by Dunnett's t-test was used to determine statistically significant differences between means. Results were considered significant at $p<0.05$. All the data analysis and statistical analysis were done using Microsoft Excel version 13.0 and Statistical Package for Social Sciences version 22.0 .

\section{RESULTS}

\section{Phytochemical screening}

A series of chemical reactions were performed for the qualitative assessment of phytochemicals present in the crude methanolic extract of $G$. tetrandra leaves. Table 1 summarizes the results of different chemical tests used to detect and identify chemical constituents.

\section{Acetic acid-induced analgesic activity}

According to the statistical analysis, the extract in both doses exerted a dose-dependant analgesic activity in mice (Table 2). In this experiment, the reference drug (diclofenac sodium) $50 \mathrm{mg} / \mathrm{kg}$ and G. tetrandra leaf extract at 200 and $400 \mathrm{mg} /$ $\mathrm{kg}$ significantly reduced the mean number of abdominal constrictions or writhes.

\section{Sedative-hypnotic activity}

\section{(i) Hole board test}

The effect of the plant extract as a sedative on mice using the hole board test is summarized in Table 3. The observed results suggest that the leaf extract of $G$. tetrandra possesses the significant potential to having a sedative-hypnotic activity compared to the standard.

\section{Table 1. Phytochemical screening of methanolic extract of} Gomphandra tetrandra leaves

\begin{tabular}{ll} 
Phytochemicals & Outcomes \\
\hline Phytosterols & ++ \\
\hline Steroids & +++ \\
\hline Carbohydrates & +++ \\
\hline Saponins & - \\
\hline Gums and mucillages & +++ \\
\hline Soluble starch & - \\
\hline Cardiac glycosides & - \\
\hline Anthraquinone glycosides & - \\
\hline Tannins & - \\
\hline Flavonoids & ++ \\
\hline Proteins & - \\
\hline Terpenoids & - \\
\hline
\end{tabular}

(+): Detected, (-): Not detected

Table 2. Analgesic activity of methanolic extract of Gomphandra tetrandra leaf in the acetic acid-induced writhing test

\begin{tabular}{lll} 
Group & No of writhing & $\begin{array}{l}\% \text { of inhibition } \\
\text { functions }\end{array}$ \\
\hline Control & $21.25 \pm 2.87$ & - \\
\hline Standard & $3.75 \pm 0.96$ & $82.35^{\star * *}$ \\
\hline Extract $(200 \mathrm{mg} / \mathrm{g})$ & $8.5 \pm 1.00$ & $60.00^{\star *}$ \\
\hline Extract $(400 \mathrm{mg} / \mathrm{kg})$ & $5 \pm 0.82$ & $76.47^{\star * \star}$ \\
\hline
\end{tabular}

The number of writhing is expressed as a mean + SEM (n: 5 ), and significance of the percentage of inhibition writhing is determined compared to the control group, where ${ }^{* \star} p<0.01,{ }^{* \star *} p<0.001$, SEM: Standard error of mean 


\section{(ii) Open field test}

The observed result reveals that the extracts substantially $(p<0.05)$ decreased the mice's locomotion in the open field examination. The suppressive effect began after $30 \mathrm{~min}$ and lasted until $120 \mathrm{~min}$, after the extract was administered. The impact of the plant extract on the animal model using the open field test is summarized in Table 4. This suggested that the extract at both doses has significant activity.

\section{(iii) Hole cross test}

The effect of the plant extract as a sedative-hypnotic using the hole cross test is summarized in Table 5. This suggested that the extract at both doses has significant activity compared to the standard.

\section{DISCUSSION}

The findings of this study demonstrated that the extract of G. tetrandra leaf possessed analgesic activity evident in the

Table 3. Effect of the Gomphandra tetrandra leaf extract as sedative-hypnotics on hole board test

\begin{tabular}{lll} 
Treatment & $\begin{array}{l}\text { Head dips } \\
\text { mean } \pm \text { SD }\end{array}$ & \% Inhibition \\
\hline Control & $20.5 \pm 0.58$ & - \\
\hline Standard & $4 \pm 0.82$ & $80.49^{\star * *}$ \\
\hline Extract $(200 \mathrm{mg} / \mathrm{kg})$ & $7.25 \pm 0.96$ & $64.63^{\star * *}$ \\
\hline Extract $(400 \mathrm{mg} / \mathrm{kg})$ & $2.75 \pm 0.96$ & $86.59^{\star * *}$ \\
\hline
\end{tabular}

Values are expressed in mean \pm SD (n: 5), where, ${ }^{* \star *} p<0.001$. SD: Standard deviation

Table 4. Effect of the Gomphandra tetrandra leaf extract as an antidepressant in the open field test

\begin{tabular}{|c|c|c|c|c|c|c|c|}
\hline \multirow{2}{*}{$\begin{array}{l}\text { Time interval } \\
\text { (minute) }\end{array}$} & \multicolumn{4}{|c|}{ Mean \pm SD value of four groups (number of square crossing) } & \multicolumn{3}{|l|}{$\%$ Inhibition } \\
\hline & $\begin{array}{l}\text { Control } \\
(10 \mathrm{~mL} / \mathrm{kg})\end{array}$ & $\begin{array}{l}\text { Standard } \\
(100 \mathrm{mg} / \mathrm{kg})\end{array}$ & $\begin{array}{l}\text { Extract } \\
(200 \mathrm{mg} / \mathrm{kg})\end{array}$ & $\begin{array}{l}\text { Extract } \\
(400 \mathrm{mg} / \mathrm{kg})\end{array}$ & $\begin{array}{l}\text { Standard } \\
(100 \mathrm{mg} / \mathrm{kg})\end{array}$ & $\begin{array}{l}\text { Extract } \\
(200 \mathrm{mg} / \mathrm{kg})\end{array}$ & $\begin{array}{l}\text { Extract } \\
(400 \mathrm{mg} / \mathrm{kg})\end{array}$ \\
\hline 30 & $54 \pm 1.83$ & $17.75 \pm 0.96$ & $33.25 \pm 2.75$ & $22.25 \pm 0.50$ & $67.13^{\star \star \star}$ & $38.43^{\star \star *}$ & $58.80 * \star \star$ \\
\hline 60 & $56.75 \pm 2.06$ & $10.25 \pm 1.26$ & $31 \pm 2.16$ & $21 \pm 1.83$ & $81.94^{\star * *}$ & $45.37^{\star \star *}$ & $63.11^{* * *}$ \\
\hline 90 & $59.5 \pm 1.29$ & $7.5 \pm 1.29$ & $26.25 \pm 2.50$ & $16.25 \pm 0.50$ & $87.39 * * *$ & $55.88^{\star \star *}$ & $72.69 * * *$ \\
\hline 120 & $56.5 \pm 1.29$ & $4.75 \pm 0.50$ & $31.5 \pm 4.20$ & $20.25 \pm 0.96$ & $91.59 * * \star$ & $44.25^{\star \star \star}$ & $64.16^{\star * *}$ \\
\hline
\end{tabular}

${ }^{* * *} p<0.001$. SD: Standard deviation

Table 5. Effect of the Gomphandra tetrandra leaf extract as antidepressants on hole cross test

\begin{tabular}{|c|c|c|c|c|c|c|c|}
\hline \multirow{2}{*}{$\begin{array}{l}\text { Time interval } \\
\text { (minute) }\end{array}$} & \multicolumn{4}{|c|}{$\begin{array}{l}\text { Hole crossing } \\
\text { Mean } \pm S D \text { value of four groups }\end{array}$} & \multicolumn{3}{|l|}{$\%$ Inhibition } \\
\hline & $\begin{array}{l}\text { Control } \\
(10 \mathrm{~mL} / \mathrm{kg})\end{array}$ & $\begin{array}{l}\text { Standard } \\
(100 \mathrm{mg} / \mathrm{kg})\end{array}$ & $\begin{array}{l}\text { Extract } \\
(200 \mathrm{mg} / \mathrm{kg})\end{array}$ & $\begin{array}{l}\text { Extract } \\
(400 \mathrm{mg} / \mathrm{kg})\end{array}$ & $\begin{array}{l}\text { Standard } \\
(100 \mathrm{mg} / \mathrm{kg})\end{array}$ & $\begin{array}{l}\text { Extract } \\
(200 \mathrm{mg} / \mathrm{kg})\end{array}$ & $\begin{array}{l}\text { Extract } \\
(400 \mathrm{mg} / \mathrm{kg})\end{array}$ \\
\hline 30 & $10.75 \pm 1.26$ & $4.25 \pm 0.96$ & $7.75 \pm 0.96$ & $4.5 \pm 1.29$ & $60.47^{\star \star \star}$ & $27.91^{*}$ & $58.14^{\star \star \star}$ \\
\hline 60 & $12.75 \pm 0.50$ & $3.5 \pm 0.58$ & $8 \pm 0.82$ & $4.5 \pm 0.58$ & $72.55^{\star \star \star}$ & $37.25^{\star \star \star}$ & $64.71^{\star \star \star}$ \\
\hline 120 & $12.5 \pm 1.73$ & $2.75 \pm 0.50$ & $6.5 \pm 0.58$ & $3.75 \pm 0.50$ & $78^{\star \star \star}$ & $48^{\star \star *}$ & $70^{\star \star \star}$ \\
\hline
\end{tabular}

Values are expressed in mean \pm SD (n: 5), ${ }^{*} p<0.05,{ }^{* * *} p<0.001$. SD: Standard deviation model, which suggests the presence of peripherally mediated mechanisms. The acetic acid-induced writhing response is a commonly used method for determining the peripheral analgesic function of any plant component. In an animal model, acetic acid is a primary pain inducer..$^{22}$ Several studies revealed that the pain response induced by acetic acid involves peritoneal mast cells and prostaglandin pathways. ${ }^{23,24}$ The intraperitoneal administration of acetic acid has enriched the release of some inflammatory mediators, including histamine, serotonin, substance $P$, prostaglandins, and bradykinin. The release of these inflammatory mediators produces further abdominal constriction or discomfort..$^{25}$ Deraedt et al. ${ }^{26}$ reported accumulation of prostaglandins PGE2e PGF2 within 30 min of acetic acid injection. Jiang et al. ${ }^{27}$ also found an elevated level of lipoxygenase enzyme in peritoneal fluid following intraperitoneal acetic acid injection. Various flavonoids, including rutin, quercetin, pectolinarin, and gossypin, have been shown to induce considerable analgesic activity in various pain tests in previous studies. ${ }^{28}$ Therefore, the flavonoids' involvement in the extract could play a vital role in the observed analgesic activity as they findings also provide scientific credence for the traditional use of the leaf of $G$. tetrandra as an analgesic.

The obtained results suggest that the methanolic leaf extract of $G$. tetrandra possesses significant neuropharmacological activity in the animal model. The sedative-hypnotic activity was carefully assessed based on motor activity and exploratory behavior in the hole board, open field, and hole cross test. The open field is the most popular observational approach for general motor function. The most significant advantage of assessing motor movement in the open field is that the trend may inhibit the release of these inflammatory mediators. These 
and qualitative profile of action can be detected explicitly. ${ }^{29}$ Moreover, the hole board test has also achieved wide acceptance to assess the sedative-hypnotic activity of any drugs in the rodent model. Hole-poking (also known as head-dipping) is a standard prepotent action proven to be highly responsive to drug effects. ${ }^{30}$ There are many physiologic conditions that can potentiate insomnia and other sleep disorders. Nervousness, tension, and indecision, both of which are accompanied by physiological arousal, may exacerbate sleep disruptions. ${ }^{31}$ Synaptic transmission inhibition is required in this case, and agonists of the $\gamma$-aminobutyric acid receptor type $A\left(G A B A_{A}\right)$ are commonly used to achieve this (e.g., benzodiazepines). ${ }^{32}$

Furthermore, muscle fatigue, reduced ambulatory function, and sedation are well-known results of CNS depressant medications like benzodiazepines. ${ }^{33,34}$ Plants containing flavonoids and tannins are well-known for their ability to treat various CNS disorders. ${ }^{35}$ As a consequence, the extract's sedative-hypnotic properties are most likely attributed to the flavonoids coupling to the $\mathrm{GABA}_{\mathrm{A}}$-benzodiazepine complex.

\section{CONCLUSION}

Phytochemical screening revealed that the methanolic extract of $G$. tetrandra contains steroids, carbohydrates, phytosterols, gums, flavonoids, and mucilages. The leaf extract of $G$. tetrandra is endowed with the significant potential of having analgesic and sedative-hypnotic activity. It reduced the pain of mice, where acetic acid was injected intraperitoneally. The results of these in vivo experiments inspire us to investigate the animals' motor performance further to determine the potentiality of antinociceptive involvement in the central and peripheral nervous systems. However, the findings demand a more of-depth investigation in animal models to uncover the molecular mechanisms of action in analgesic and sedativehypnotic activity.

\section{Ethics}

Ethics Committee Approval: Approved by the local Ethics Committee (ref. no: DoP/RC/EC/2020/06/02).

Informed Consent: Not applicable.

Peer-review: Externally peer-reviewed.

\section{Authorship Contributions}

Concept: N.M.M.A.B., Design: M.H., N.M.M.A.B., Data Collection or Processing: M.F.H., Analysis or Interpretation: N.M.M.A.B., M.M.I., Literature Search: N.M.M.A.B., M.H., Writing: N.M.M.A.B., M.M.I., M.H.

Conflict of Interest: No conflict of interest was declared by the authors.

Financial Disclosure: The authors declared that this study received no financial support.

\section{REFERENCES}

1. Farnsworth N, Soejarto D. Global importance of medicinal plants. In Akerele O, Heywood V, Synge H (eds.). Conservation of Medicinal Plants. 1991;25-52.
2. Samuelsson G, Bohlin L. Drugs of natural origin: a treatise of Pharmacognosy. CRC Press Inc.; 2017.

3. Ghani A. Medicinal plants of bangladesh: chemical constituents and uses. Asiatic Society of Bangladesh. 1998;467.

4. Dimitrov K, Metcheva D, Boyadzhiev L. Integrated processes of extraction and liquid membrane isolation of atropine from Atropa belladonna roots. Sep Purif Technol. 2005;46:41-45.

5. Ziegler J, Diaz-Chávez ML, Kramell R, Ammer C, Kutchan TM. Comparative macroarray analysis of morphine containing Papaver somniferum and eight morphine free Papaver species identifies an 0 -methyltransferase involved in benzylisoquinoline biosynthesis. Planta. 2005;222:458-471.

6. Kavishankar GB, Lakshmidevi N, Mahadeva Murthy S. Phytochemical analysis and antimicrobial properties of selected medicinal plants against bacteria associated with diabetic patients. Int J Pharm Biosci. 2011;2:509-518.

7. Tewari DN. Report of the task force on conservation and sustainable use of medicinal plants. Bulletin of Planning Commission, Government of India, New Delhi, India. Published online: 2000.

8. Byng JW, Bernardini B, Joseph JA, Chase MW, Utteridge TM. Phylogenetic relationships of Icacinaceae focusing on the vining genera. Bot J Linn Soc. 2014;176:277-294.

9. Ramesha BT, Suma HK, Senthilkumar U, Priti V, Ravikanth G, Vasudeva R, Kumar TR, Ganeshaiah KN, Shaanker RU. New plant sources of the anti-cancer alkaloid, camptothecine from the Icacinaceae taxa, India. Phytomedicine. 2013;20:521-527.

10. Fang D, Zuo D. Two new species of Adinandra and Mappianthus from Guangxi, China. Acta Bot Yunnan. 2002;24:709-711.

11. Nwidu LL, Teme RE. Hot aqueous leaf extract of Lasianthera africana (Icacinaceae) attenuates rifampicin-isoniazid-induced hepatotoxicity. J Integr Med. 2018;16:263-272.

12. Ekanem NG, Mbagwu HOC, Harry Gl. Phytochemical screening and hypoglycaemic activity of Lasianthera africana Beauv. (Aquifoliales: Stemonuraceae) leaf extract on diabetic rats. Braz J Biol Sci. 2016;3:293298.

13. Ekpo DE, Joshua PE, Ogidigo JO, Nwodo OF. High resolution UPLC-PDAQTOF-ESI-MS/MS analysis of the flavonoid-rich fraction of Lasianthera africana leaves, and in vivo evaluation of its renal and cardiac function effects. Heliyon. 2020;6:e04154.

14. Goshwami D, Rahman MM, Muhit MA, Islam S. In-vitro evaluation of anthelmintic activity of Lasia spinosa leaves. Int J Curr Pharm Res. 2013;5:34-35

15. Raka SC, Rahman A, Hussain F, Rahman SMA. Synthesis, characterization and in vitro, in vivo, in silico biological evaluations of substituted benzimidazole derivatives. Saudi J Biol Sci. 2022;29:239-250.

16. Demers G, Griffin G, De Vroey G, Haywood JR, Zurlo J, Bédard M. Harmonization of animal care and use guidance. Science. 2006;312:700701.

17. Osborne N, Avey MT, Anestidou L, Ritskes-Hoitinga M, Griffin G. Improving animal research reporting standards: HARRP, the first step of a unified approach by ICLAS to improve animal research reporting standards worldwide. EMBO Rep. 2018;19:e46069.

18. Bhuiya NM, Hasan M, Mahmud ZA, Qais N, Kabir MS, Ahmed F, Uddin MM. In vivo analgesic, antipyretic and anti-inflammatory potential of leaf extracts and fractions of Eria javanica. J Complement Integr Med. 2017;14. 
19. Crawley JN. Exploratory behavior models of anxiety in mice. Neurosci Biobehav Rev. 1985;9:37-44.

20. Gupta BD, Dandiya PC, Gupta ML. A psycho-pharmacological analysis of behavior in rats. Jpn J Pharmacol. 1971;21:293-298.

21. Takagi K, Watanabe M, Saito H. Studies of the spontaneous movement of animals by the hole cross test; effect of 2-dimethyl-aminoethanol and its acyl esters on the central nervous system. Jpn J Pharmacol. 1971;21:797810.

22. Bhuiyan MMR, Bhuiya NMMA, Hasan MN, Nahar UJ. In vivo and in silico evaluation of antinociceptive activities of seed extract from the Holarrhena antidysenterica plant. Heliyon. 2020;6:e03962.

23. Ribeiro RA, Vale ML, Thomazzi SM, Paschoalato AB, Poole S, Ferreira $\mathrm{SH}$, Cunha FQ. Involvement of resident macrophages and mast cells in the writhing nociceptive response induced by zymosan and acetic acid in mice. Eur J Pharmacol. 2000;387:111-118.

24. Vogel HG. Drug discovery and evaluation: pharmacological assays. Springer Science \& Business Media; 2002.

25. Ikeda $\mathrm{Y}$, Ueno A, Naraba H, Oh-ishi S. Involvement of vanilloid receptor VR1 and prostanoids in the acid-induced writhing responses of mice. Life Sci. 2001;69:2911-2919.

26. Deraedt R, Jouquey S, Delevallée F, Flahaut M. Release of prostaglandins $E$ and $F$ in an algogenic reaction and its inhibition. Eur $\mathrm{J}$ Pharmacol. 1980;61:17-24.

27. Jiang B, Huang X, Yao H, Jiang J, Wu X, Jiang S, Wang Q, Lu T, Xu J. Discovery of potential anti-inflammatory drugs: diaryl-1, 2, 4-triazoles bearing $N$-hydroxyurea moiety as dual inhibitors of cyclooxygenase-2 and 5-lipoxygenase. Org Biomol Chem. 2014;12:2114-2127.

28. Calixto JB, Beirith A, Ferreira J, Santos AR, Filho VC, Yunes RA. Naturally occurring antinociceptive substances from plants. Phytother Res. 2000;14:401-418.

29. Denenberg VH. Open-field behavior in the rat: what does it mean? Ann N Y Acad Sci. 1969;159:852-859.

30. Kelley AE. Locomotor activity and exploration. Techniques in the Behavioral and Neural Sciences. 1993:499-518.

31. Spielberger CD. State-trait anxiety inventory. The Corsini Encyclopedia of Psychology. Hoboken: Wiley. 2010;1.

32. Tobler I, Kopp C, Deboer T, Rudolph U. Diazepam-induced changes in sleep: role of the alpha $1 \mathrm{GABA}(\mathrm{A})$ receptor subtype. Proc Natl Acad Sci U S A. 2001;98:6464-6469.

33. Farkas S, Berzsenyi P, Kárpáti E, Kocsis P, Tarnawa I. Simple pharmacological test battery to assess efficacy and side effect profile of centrally acting muscle relaxant drugs. J Pharmacol Toxicol Methods. 2005;52:264-73.

34. López-Rubalcava C, Hen R, Cruz SL. Anxiolytic-like actions of toluene in the burying behavior and plus-maze tests: differences in sensitivity between 5-HT(1B) knockout and wild-type mice. Behav Brain Res. 2000;115:85-94.

35. Adeyemi OO, Yemitan OK, Taiwo AE. Neurosedative and musclerelaxant activities of ethyl acetate extract of Baphia nitida AFZEL. J Ethnopharmacol. 2006;106:312-316. 